\title{
Combined Effects of Temperature and Salinity on Larval Development of the Mangrove Crab Parasesarma catenata Ortman, 1897 (Brachyura: Sesarmidae)
}

\author{
José Paula', Ricardo Nogueira Mendes' ${ }^{1}$, James Mwaluma ${ }^{2}$, Claudia Raedig' and \\ Winston Emmerson ${ }^{3}$

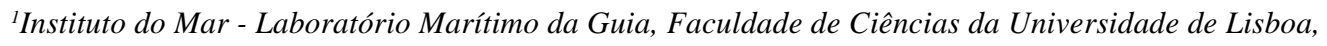 \\ Estrada do Guincho, 2750-642 Cascais, Portugal; ${ }^{2}$ Kenya Marine Fisheries and Research Institute, Cement \\ Road, P.O. Box 81651, Mombasa, Kenya; ${ }^{3}$ Department of Zoology, University of Transkei, P. Bag X1, 5117 \\ Umtata, South Africa
}

Key words: larval development, temperature, salinity, Brachyura, mangroves

\begin{abstract}
The larval stages of the mangrove crab Parasesarma catenata were reared in the laboratory from eggs of females collected in the Mgazana estuary, South Africa. Survival and duration of larval stages were tested for the combined effects of temperature and salinity in a factorial design experiment, using three females each with two replicates of 15 larvae per combination. Combinations were made from five temperature $\left(15,20,25,30\right.$ and $\left.35^{\circ} \mathrm{C}\right)$ and four salinity values $(15,25,35$ and $45 \%$ ). Results were tested by ANOVA and multiple regression was applied to generate contour models by polynomial equation. It was found that $P$. catenata larvae develop optimally in near to seawater salinity at a temperature of around $25^{\circ} \mathrm{C}$. These results support the assumption that newly-hatched larvae of this species are exported from the estuarine environment to the sea for development.
\end{abstract}

\section{INTRODUCTION}

Tropical mangrove habitats are generally brackish water environments, and have endemic brachyuran species most of which show an 'exportation' life cycle strategy (e.g. Dittel et al., 1991; Paula et al. 2000), as found in estuaries in general (Queiroga, 1996). Newly-hatched larvae immigrate by passive and active mechanisms to adjacent shelf waters, using selective stream tidal transport (Queiroga et al., 1997; Queiroga, 1998). This mechanism is thought to be important for avoidance of estuarine environmental stress and high predation pressure (Paula, 1989). The variability of water masses, which affects larvae during development, may have a major impact on their survival, transport and ultimately recruitment success.

One of major factors accounting for estuarine stress is salinity, as osmoregulatory capability develops throughout the larval sequence of stages (Charmantier, 1998), and most newly-hatched stages are regarded as being more sensitive to low salinity (Charmantier et al., 2002). However, in some freshwater species hatching occurs in freshwater with subsequent seaward exportation, and in this case the newly-hatched stage has strong osmoregulation capability (Charmantier et al., 1998). Within a tolerated range, temperature mostly affects duration of larval stages, and these effects in turn affect dispersal and gene flow interacting with coastal physical processes (Crisp, 1976). Larval survival is thus strongly affected by temperature and salinity (Sandifer, 1973; Paula et al., 2001a), although each species' tolerance will be specific for its degree of adaptation to the environmental gradients of coastal systems. 
Sesarmid crabs, one of major crustacean families in mangrove systems, occupy a wide diversity of aquatic habitats from nearly marine to freshwater. Their adaptation to different and often varying-salinity environments has resulted in a gradient of osmoregulatory capabilities and life cycle strategies in the crabs. The effects of temperature and salinity on larval development of sesarmid crabs have been studied in a number of species, such as Sesarma cinereum (Costlow et al., 1960), S. rectum (Fransozo \& Negreiros-Fransozo, 1986), Aratus pisonii (Diaz \& Bevilacqua, 1986), S. angustipes (Anger et al., 1990), S. recordi (Alvarez \& Ewald, 1990), S. reticulatum (Paula et al., 1992), Armases miersii (Schuh \& Diesel, 1995a), S. curacoense (Schuh \& Diesel, 1995b), Arm. ricordi and Arm. roberti (Diesel \& Schuh, 1998).

Parasesarma catenata is one of the most common species of estuarine marsh crabs in southern Africa, with a distribution extending from the Bree River to Inhaca Island, Mozambique (Kensley, 1981; Day, 1981). In southern Cape estuaries it is found in high densities within Spartina salt-marshes, while in the Transkei, KwaZulu Natal and southern Mozambique this species is associated with mangrove swamps. Its larval development has four zoeal and a megalopa stage as described by Pereyra-Lago (1987). In the Mgazana estuary, South Africa, the breeding season for P. catenata starts around August (Emmerson, 1994), and newly-hatched stages are effectively exported from the estuarine environment (Pereyra-Lago, 1993).

The objective of this work was to study the temperature and salinity effects on larval development of Parasesarma catenata, in relation to survival and duration of larval stages. To accomplish this aim, a factorial designed experiment was carried out in the laboratory under controlled conditions.

\section{MATERIALS AND METHODS}

\section{Female collection}

Ovigerous females of Parasesarma catenata were hand-collected in the mangrove swamp among Avicennia marina trees in Mgazana estuary, Transkei coast in South Africa. Ovigerous females were transported to the marine laboratory of
University of Transkei, Umtata. The crabs were maintained individually without food at $25^{\circ} \mathrm{C}$ and at a salinity of $35 \%$ until hatching.

\section{Experimental design}

The experiment followed a factorial design, and combinations were made from five temperatures $(15$, $20,25,30$ and $\left.35^{\circ} \mathrm{C}\right)$ and four salinities $(15,25,35$ and $45 \%$ ). In each combination 3 random females were used from a minimum set of 6 hatchings, each female with 2 replicates of 15 larvae. Larvae were chosen from amongst the most active of respective batches. Each replicate was cultured in $400 \mathrm{ml}$ glass bowls. Water was periodically brought from the shore, and filtered through a series of Millipore filters down to $0.5 \mu \mathrm{m}$. Dilution was done using de-ionised water and concentration was obtained by evaporation. Temperatures were regulated in enclosed chambers to precision of within $\pm 0.5^{\circ} \mathrm{C}$.

Larvae were transferred to new cultures each day and fed on newly-hatched Artemia nauplii. While transferring, larvae were checked for mortality and sorted by developmental stage. At high temperatures $\left(30\right.$ and $\left.35^{\circ} \mathrm{C}\right)$ the cultures were covered with adhesive plastic to prevent evaporation and consequent salinity increase. The experiment lasted until the juvenile stage was reached.

Temperature and salinity effects on survival of larval stages were tested by 2-way factorial ANOVA. Percent cumulative survival was transformed by angular transformation (arcsin $\checkmark$ proportion). Regression coefficients were used in the polynomial expression to generate a surface response contour (Box \& Youle, 1955):

$\mathrm{Z}=\mathrm{b}_{0}+\mathrm{b}_{1} \mathrm{~T}+\mathrm{b}_{2} \mathrm{~S}+\mathrm{b}_{11} \mathrm{~T}+\mathrm{b}_{22} \mathrm{~S}+\mathrm{b}_{12} \mathrm{TS}$

where $\mathrm{Z}$ is the surface response, $\mathrm{T}$ is temperature, $\mathrm{S}$ is salinity, $\mathrm{b}_{0}$ is the multiple regression constant, $b_{1}$ and $b_{2}$ are the linear effects of temperature and salinity, $b_{11}$ and $b_{22}$ are the quadratic effects, and $\mathrm{b}_{12}$ is the intersection effect. No statistical test was applied to duration of larval stages, as total mortality in a number of extreme temperature and salinity combinations makes the planned comparisons highly unbalanced and of restricted interpretation value. 


\section{RESULTS}

The cumulative sequence of larval stages obtained in the various temperature and salinity combinations is presented in Fig. 1. It is clear that for the tested ranges of temperature and salinity it is the latter which mostly affects the survival of the larval stages, especially at lower ranges. At the lowest salinity tested $(15 \%$ o $)$ and at the lower and higher temperature $\left(15,20\right.$ and $\left.35{ }^{\circ} \mathrm{C}\right)$ combinations, complete mortality for stage I was obtained, with low survival for the next stages at 25 and $35^{\circ} \mathrm{C}$. At the lowest temperature $\left(15^{\circ} \mathrm{C}\right)$ and higher salinities (35 and $45 \%$ ), there were good survival rates for the zoeal stages, but no larvae reached the megalopa stage. The combinations which produced juvenile stages were between 20 and $30{ }^{\circ} \mathrm{C}$ and between 25 and $45 \%$ o salinity. Duration to megalopa was shorter at $30^{\circ} \mathrm{C}$ than at 20 and $25^{\circ} \mathrm{C}$, but survival rates were higher at 20 and $25^{\circ} \mathrm{C}$ than at $30^{\circ} \mathrm{C}$.
Figure 2 presents the results of cumulative survival in the temperature and salinity combinations for each larval stage. For all zoeal stages the highest survival was obtained at $25^{\circ} \mathrm{C}$ (with very similar results at 20 and $30^{\circ} \mathrm{C}$ ), with sea water salinity (35\%o), but survival decreased towards the lower and higher values of the salinity tested. The lowest salinity (15) induced the lowest survival-nearly all first zoeal larvae died at all the temperatures tested.

The results of cumulative duration of larval stages were not consistent with the results obtained for survival, i.e. the optimal points for survival are not coincident with the highest developmental rate up to a certain degree (Fig. 3). The developmental rate at $30{ }^{\circ} \mathrm{C}$ was faster than at any other temperature, and this trend was consistent for all salinity values.

ANOVA results showed not only that both temperature and salinity have significant effects on survival for all larval stages (Table 1), but also

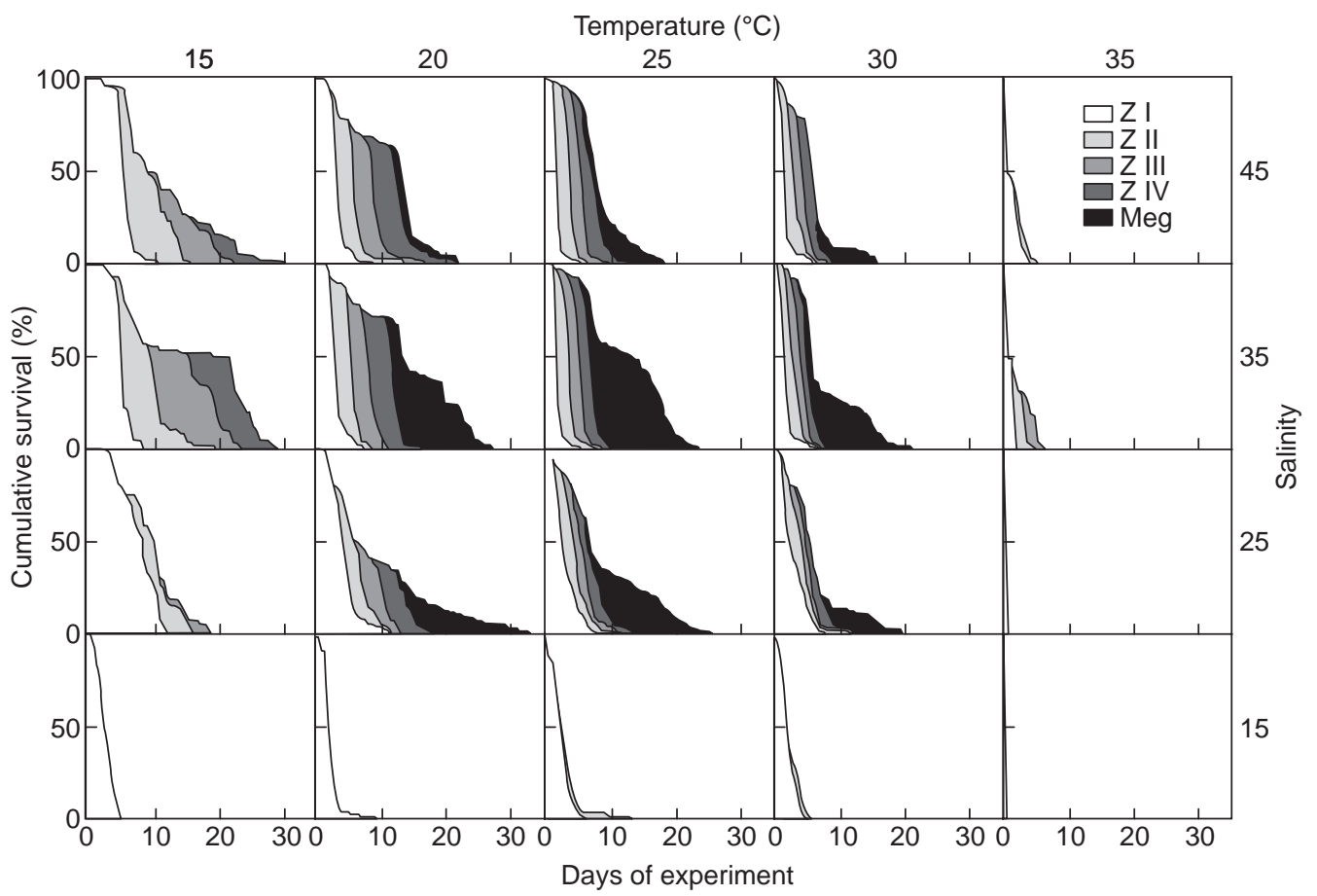

Fig. 1. Survival of sequence of developmental stages of Parasesarma catenata obtained in the temperature and salinity combinations. ZI to ZIV - zoeal stages I to IV, Meg - megalopa. 


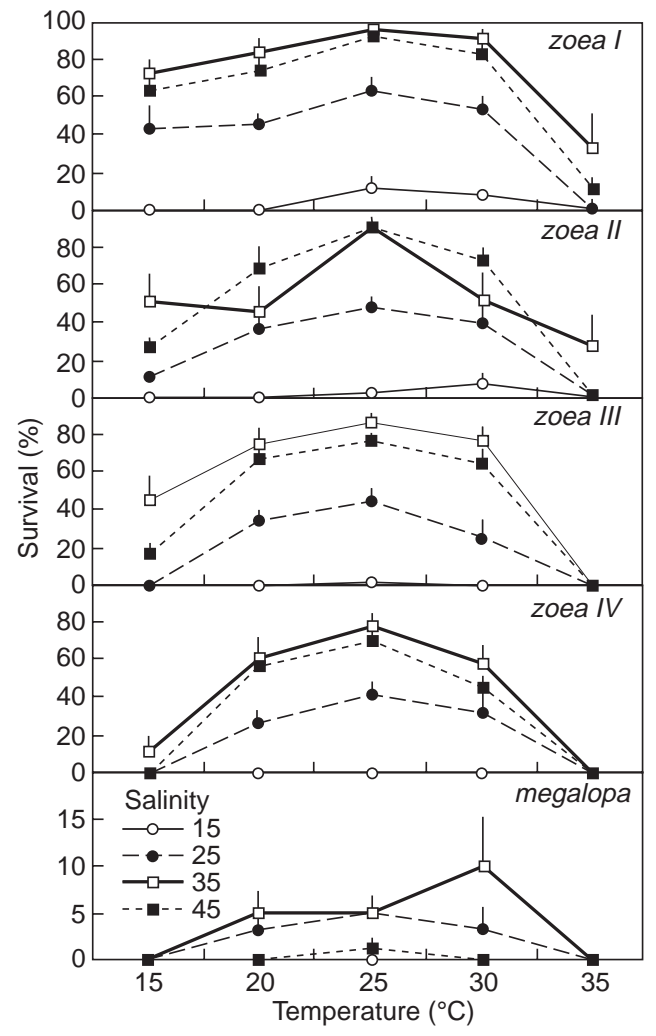

Fig. 2. Average cumulative survival of sequence of larval stages of Parasesarma catenata obtained in the temperature and salinity combinations. Error bars refer to standard error

Table 1. Results of a 2-way ANOVA for survival of zoae I to megalopa Parasesarma catenata for salinity and temperature matrix. ZI-ZIV, zoeal stages I to IV; T, temperature; $S$, salinity

\begin{tabular}{lrrrr}
\hline Source & MS & DF & \multicolumn{1}{c}{ F } & P-level \\
\hline ZI & & & & \\
T & 2.114 & 4 & 43.11 & $<0.0001$ \\
S & 5.465 & 3 & 111.48 & $<0.0001$ \\
T x S & 0.136 & 12 & 2.78 & 0.0027 \\
ZII & & & & \\
T & 1.941 & 4 & 44.66 & $<0.0001$ \\
S & 4.590 & 3 & 105.63 & $<0.0001$ \\
T x S & 0.235 & 12 & 5.42 & $<0.0001$ \\
ZIII & & & & \\
T & 2.184 & 4 & 62.56 & $<0.0001$ \\
S & 3.591 & 3 & 102.85 & $<0.0001$ \\
T x S & 0.283 & 12 & 8.11 & $<0.0001$ \\
ZIV & & & & \\
T & 2.224 & 4 & 64.68 & $<0.0001$ \\
S & 2.068 & 3 & 60.12 & $<0.0001$ \\
T x S & 0.282 & 12 & 8.21 & $<0.0001$ \\
\hline & & & & \\
\hline & & & &
\end{tabular}

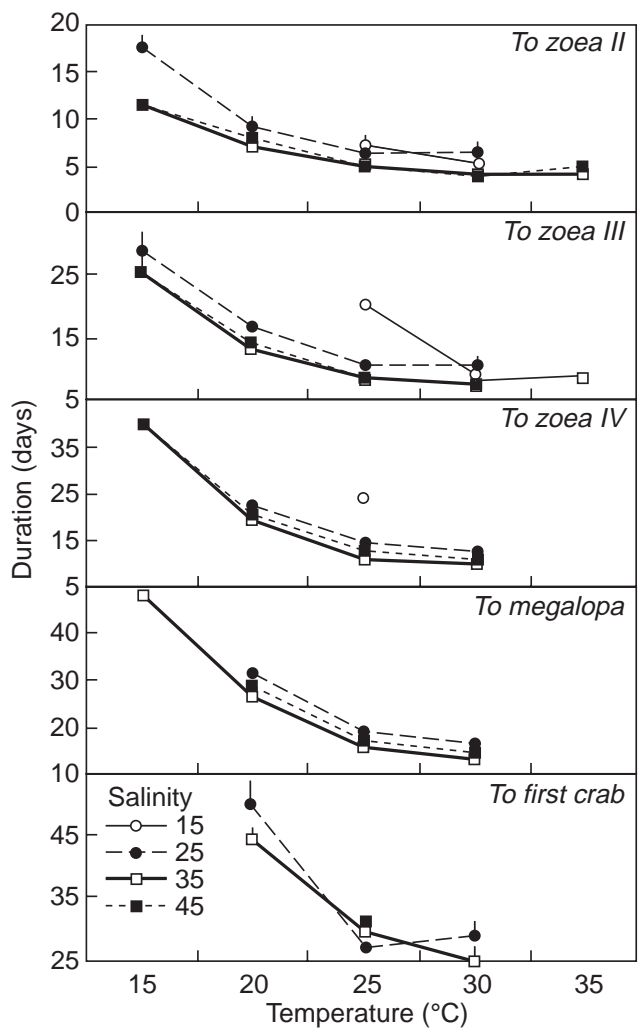

Fig. 3. Average cumulative duration of sequence of larval stages of Parasesarma catenata obtained in the temperature and salinity combinations. Error bars refer to standard error

their interaction. Overall the result of analysis of variance for mortality was a fully significant matrix for larval stages, factors and their interaction.

Contour analysis defines clear centres of optimal combinations of temperature and salinity for the survival of Parasesarma catenata larval stages (Fig. 4). The optimal points of salinity are close to full salinity seawater, and temperature is within the expected normal range for summer condition in the area $\left(20\right.$ to $\left.27^{\circ} \mathrm{C}\right)$.

\section{DISCUSSION}

The larval stages of estuarine species, especially the megalopa, encounter a changing estuarine environment, especially in salinity, when migrating back to parental areas. Although their survival can physiologically be similar to the previous stages, the acceleration of the moulting process with a lowering in salinity can account for increasing 


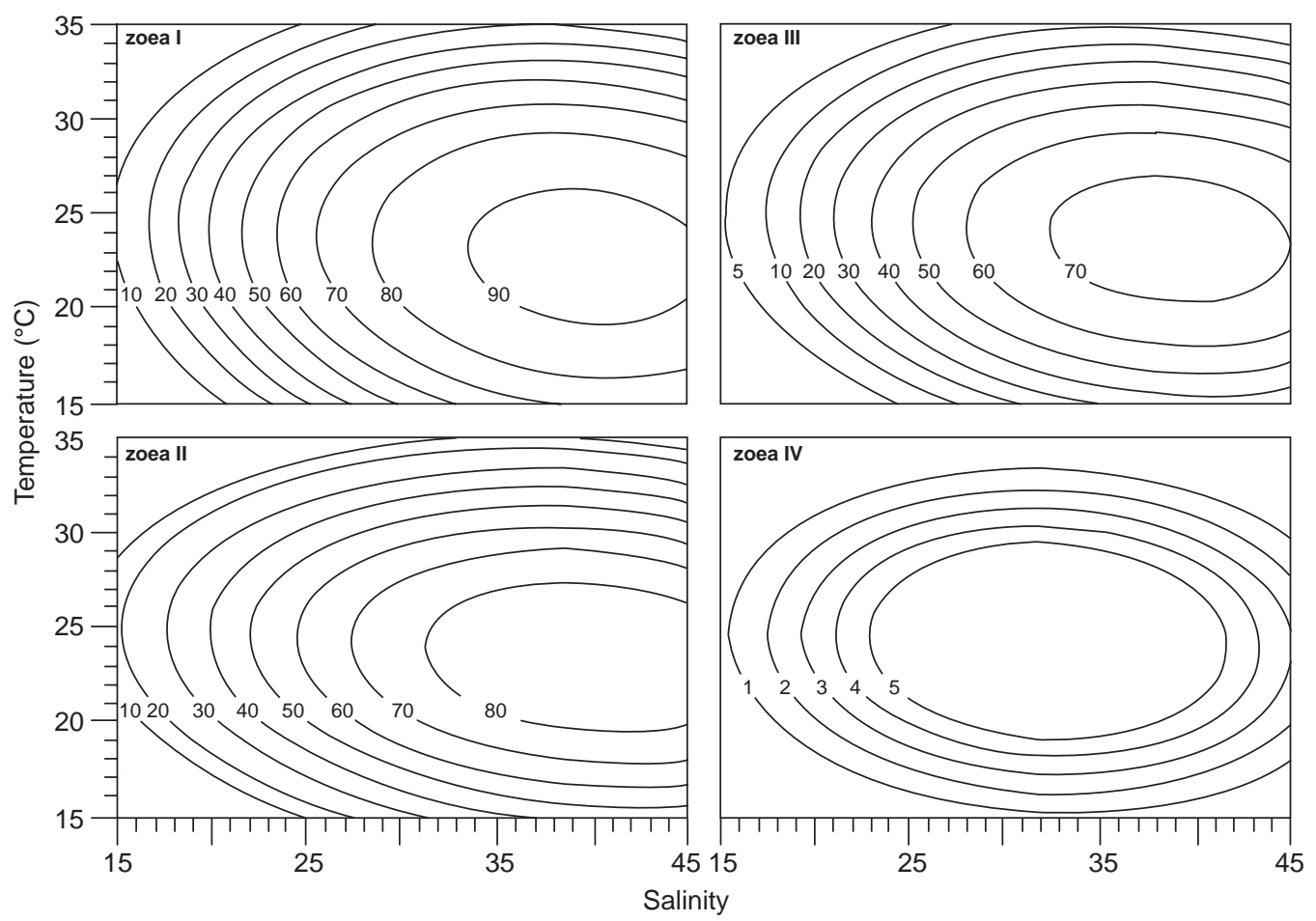

Fig. 4. Contour plots for survival of larval stages of Parasesarma catenata in the tested temperature and salinity matrix

survival. Several studies, however, refer to plasticity in the timing of moult for late larval stages (Sulkin \& Van Heukelem, 1986; O'Connor, 1991), which can be an adaptation to the variability of coastal waters encountered by megalopae when returning to appropriate settlement areas.

In $P$. catenata, the optimal development was found at normal sea water salinity, but with a higher tolerance for increased salinity. The duration of larval development is shorter at higher than at lower temperatures. This could be an adaptation to summer conditions in coastal systems, such as the Mgazana estuary. This estuary is stratified at the mouth with marine conditions (Branch \& Grindley, 1979), and during summer, the temperature is around $21^{\circ} \mathrm{C}$ and salinity around $32 \%$ at the bottom of the estuary. Adult populations of Parasesarma inhabit the lower estuarine region, and the species has lower tolerance to decreasing salinity (Boltt \& Heeg, 1975) than other sesarmid species.

Some species, such as Sesarma caracaoense, inhabiting mangroves, which are generally characterised by strong thermo-haline fluctuations at different temporal scales, show a wide range of tolerance (Schuh \& Diesel, 1995b). Some estuarine species, e.g. Palaemonetes varians, will maintain a wide tolerance throughout development (Antonopoulou \& Emson, 1989), showing capacity of retention in the upper part of estuaries (Paula, 1998). In estuarine species, which show an obvious strategy of larval exportation from the estuarine boundaries, salinity tolerance is narrow, with optimal development being achieved in close to full sea water salinity (e.g. Sesarma reticulatum: Paula et al., 1992; Carcinus maenas: Nagaraj, 1993), as also evident in $P$. catenata.

The present results thus corroborate the estuarine exportation type of life cycle for Parasesarma catenata, as suggested by field results by Pereyra-Lago (1993) and Paula et al. (2000). Other decapod crustacean groups in East African mangroves present similar life cycle strategies (e.g. Wooldridge \& Loubser, 1996). Larvae of several East African mangrove sesarmids have also been observed returning to parental areas from offshore (Paula et al., 2001b; 2003) as megalopal stages, strongly suggesting that most mangrove crabs have a neritic planktonic larval development. 
Acknowledgements - This work was part of the European Union research project MEAMMacrobenthos of East African Mangroves: Life Cycles and Reproductive Biology of Exploited Species. Contract no. IC18-CT96-0125. The authors would like to thank Francesca Porri, Sekiwe Mbande, Pakama Buyeye and Chumisa Thengwa for their help with field collection and cultures at Umtata, and Maria Dornelas with data processing. Acknowledgement is also due to Fundação Calouste Gulbenkian for funding the presentation of this work at the Meeting on Mangrove Macrobenthos, Kenya, 2000.

\section{REFERENCES}

Alvarez, Z. \& Ewald, J. (1990) Efectos de la salinidad y la dieta sobre el desarrollo larvario de Sesarma ricordi (Milne Edwards, 1853) (Decapoda, Grapsidae). Scient. Mar. 54: 55-60.

Anger, K., Harms, J., Montú, M. \& De Bakker, C. (1990) Effects of salinity on the larval development of a semiterrestrial tropical crab, Sesarma angustipes (Decapoda: Grapsidae). Mar. Ecol. Prog. Ser. 62: 89-94.

Antonopoulou, E. \& Emson, R. (1989) The combined effects of temperature and salinity on survival, moulting and metamorphosis of the larval stages of three species of palaemonid prawns. In: Ryland, J.S. \& Tyler, P.A. (eds) Reproduction, genetics and distributions of marine organisms. Olsen \& Olsen, Fredensborg. pp. 339-347.

Boltt, G. \& Heeg, J. (1975) The osmoregulatory ability of three grapsoid crab species in relation to their penetration of an estuarine system. Zool. Afr. 10: 167-182.

Box, G.E.P. \& Youle, P.V. (1955) The exploration and exploitation of response surfaces: an example of the link between the fitted surface and the basic mechanism of the system. Biometrics 11: 287-323.

Branch, G.M. \& Grindley, J.R. (1979) Ecology of southern African estuaries. Part XI. Mngazana: a mangrove estuary in Transkei. S. Afr. J. Zool. 14: 149-170.

Charmantier, G. (1998) Ontogeny of osmoregulation in crustaceans: a review. Inv. Reprod. Develop. 33: 177-190.

Charmantier, G., Charmantier-Daures, M. \& Anger, K. (1998) Ontogeny of osmoregulation in the grapsid crab Armases miersii (Crustacea, Decapoda). Mar. Ecol. Prog. Ser. 164: 285-292.

Charmantier, G., Giménez, L., Charmantier-Daures, M. \& Anger, K. (2002) Ontogeny of osmoregulation, physiological plasticity and larval export strategy in the grapsid crab Chasmagnathus granulata (Crustacea, Decapoda). Mar. Ecol. Prog. Ser. 229: 185-194.

Costlow, J.D., Bookhout, C.G. \& Monroe, R. (1960) The effect of salinity and temperature on larval development of Sesarma cinereum (Bosc) reared in the laboratory. Biol. Bull. 118: 183-202.

Crisp, D.J. (1976) Settlement responses in marine organisms. In: Newell, R.C. (ed.) Adaptations to environment: essays on the physiology of marine animals. Butterworths, London. pp. 83-124.

Day, J.H. (1981) The estuarine fauna. In: Day, J.H. (ed.) Estuarine ecology with particular reference to southern Africa. A.A. Balkema, Cape Town. pp. 147-178.

Diaz, H. \& Bevilacqua, M. (1986) Larval development of Aratus pisonii (Milne Edwards) (Brachyura, Grapsidae) from marine and estuarine environments reared under different salinity conditions. J. Coast. Res. 2: 43-49.

Diesel, R. \& Schuh, M. (1998) Effects of salinity and starvation on larval development of the crabs Armases ricordi and A. roberti (Decapoda: Grapsidae) from Jamaica, with notes on the biology and ecology of adults. J. Crust. Biol. 18: 423-436.

Dittel, A.I., Epifanio, C.E. \& Lizano, O. (1991) Flux of crab larvae in a mangrove creek in the Gulf of Nicoya, Costa Rica. Estuar. Coast. Shelf Sci. 32: 129-140.

Emmerson, W.D. (1994) Seasonal breeding cycles and sex ratios of eight species of crabs from Mgazana, a mangrove estuary in Transkei, southern Africa. J. Crust. Biol. 14: 568-578.

Fransozo, A. \& Negreiros-Fransozo, M.L. (1986) Influência da salinidade no desenvolvimento larval de Eriphia gonagra (Fabricius, 1781) e Sesarma (Holometopus) rectum Randall, 1840 (Crustacea, Decapoda), em laboratório. Rev. Bras. Biol. 46: 439-446.

Kensley, B. (1981) On the zoogeography of southern African decapod Crustacea, with a distributional checklist of the species. Smithson. Contr. Zool. 338: $1-64$.

Nagaraj, M. (1993) Combined effects of temperature and salinity on the zoeal development of the green crab, Carcinus maenas (Linnaeus, 1758) (Decapoda: Portunidae). Scient. Mar. 57: 1-8.

O'Connor, N.J. (1991) Flexibility in timing of the metamorphic molt by fiddler crab megalopae $U \mathrm{ca}$ pugilator. Mar. Ecol. Prog. Ser. 68: 243-247.

Paula, J. (1989) Rhythms of larval release of decapod crustaceans in the Mira Estuary, Portugal. Mar. Biol. 100: 309-312.

Paula, J. (1998) Larval retention and dynamics of the prawns Palaemon longirostris H. Milne Edwards 
and Crangon crangon Linnaeus (Decapoda, Caridea) in the Mira estuary, Portugal. Inv. Reprod. Devel. 33: 221-228.

Paula, J., Costlow, J.D., Scelzo, M.A. \& Monroe, R. (1992) Influence of temperature and salinity on the larval development of estuarine decapod crustaceans: Sesarma reticulatum Say. First European Crustacean Conference, Paris (abstract).

Paula, J., Dray, T., Nogueira Mendes, R., Bartilotti, C., Macia, A. \& Queiroga, H. (2000) Larval fluxes at Saco mangrove creek, Inhaca island (South Mozambique). In: Macrobenthos of Eastern African mangroves: life cycles and reproductive biology of exploited species. Final Report ERBIC18-CT96-0127, Part B, Florence. pp. 97111.

Paula, J., Nogueira Mendes, R., Paci, S., McLaughlin, P., Gherardi, F. \& Emmerson, W. (2001a) Combined effects of temperature and salinity on the larval development of the estuarine mud prawn Upogebia africana (Crustacea, Thalassinidea). Hydrobiologia, 449: 141-148.

Paula, J., Dray, T. \& Queiroga, H. (2001b) Interaction of offshore and inshore processes controlling settlement of brachyuran megalopae in Saco mangrove creek, Inhaca island (South Mozambique). Mar. Ecol. Prog. Ser. 215: 251-260.

Paula, J., Dornelas, M. \& Flores, A. (2003) Stratified settlement and moulting competency of brachyuran megalopae in Ponta Rasa mangrove swamp, Inhaca Island (Mozambique). Estuar. Coast. Shelf Sci. 56: 325-337.

Pereyra-Lago, R. (1987) Larval development of Sesarma catenata (Brachyura, Grapsidae, Sesarminae) reared in the laboratory. South Afr. J. Zool. 22: 200-212.

Pereyra-Lago, R. (1993) Tidal exchange of larvae of Sesarma catenata (Decapoda, Brachyura) in the Swartkops estuary, South Africa. South Afr. J. Zool. 28: 182-191.
Queiroga, H. (1996) Distribution and drift of the crab Carcinus maenas (L.) (Decapoda, Portunidae) larvae over the continental shelf off northern Portugal in April 1991. J. Plankt. Res. 18: 19812000.

Queiroga, H. (1998) Vertical migration and selective tidal stream transport in the megalopa of the crab Carcinus maenas. Hydrobiologia 375/376: 137149.

Queiroga, H., Costlow, J.D. Jr \& Moreira, M.H. (1997) Vertical migration of the crab Carcinus maenas first zoea in an estuary: implications for tidal stream transport. Mar. Ecol. Prog. Ser. 149: 121132.

Sandifer, P.A. (1973) Effects of temperature and salinity on larval development of grass shrimp, Palaemonetes vulgaris (Decapoda, Caridea). Nat. Ocean. Atmos. Admin. Fish. Bull. 71: 115-123.

Schuh, M. \& Diesel, R. (1995a) Effects of salinity, temperature and starvation on the larval development of Armases (=Sesarma) miersii (Rathbun, 1897), a semiterrestrial crab with abbreviated development (Decapoda: Grapsidae). J. Crust. Biol. 15: 205-213.

Schuh, M. \& Diesel, R. (1995b) Effects of salinity and starvation on the larval development of Sesarma curacaoense De Man, 1892, a mangrove crab with abbreviated development (Decapoda: Grapsidae). J. Crust. Biol. 15: 645-654.

Sulkin, S.D. \& Van Heukelem, W.F. (1986) Variability in the length of the megalopal stage and its consequence to dispersal and recruitment in the portunid crab Callinectes sapidus Rathbun. Bull. Mar. Sci. 39: 269-278.

Wooldridge, T.H. \& Loubser, H. (1996) Larval release rhythms and tidal exchange in the estuarine mudprawn, Upogebia africana. Hydrobiologia 337: $113-121$. 